\title{
Glucose turnover and recycling in unrestrained and unanesthetized 48-h-old fasting or post-absorptive newborn pigs
}

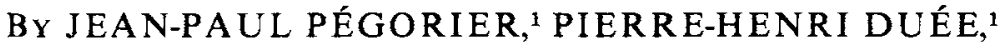 \\ CARLOS SIMOES NUNES, ${ }^{2}$ JEAN PERET ${ }^{1}$ AND J. GIRARD ${ }^{1}$ \\ ${ }^{1}$ Centre de Recherches sur la Nutrition du CNRS, 9 rue Jules Hetzel, \\ 92190 Meudon-Bellevue, France and \\ ${ }^{2}$ Laboratoire de Physiologie de la Nutrition de IINRA, CNRZ, \\ 78350 Jouy-en-Josas, France
}

(Received 24 November 1983 - Accepted 21 March 1984)

1. The metabolism of glucose has been studied in 48 -h-old unanesthetized fasting and post-absorptive sucking piglets.

2. Both $\left[6-{ }^{3} \mathrm{H}\right]-$ and $\left[\mathrm{U}-{ }^{14} \mathrm{C}\right] \mathrm{glucose}$ were administered either by a single injection method or by a primed infusion technique. The rates of glucose turnover and recycling were estimated under steady-state conditions.

3. The rates of glucose turnover and recycling in 48-h-old fasting or post-absorptive piglets were not statistically different when measured using the single injection technique or the primed infusion method.

4. The mean (with SE) rate of glucose turnover was $65.8(2.5)$ in post-absorptive and $31 \cdot 1(1.9) \mu \mathrm{mol} / \mathrm{kg} \mathrm{per}$ $\min$ in fasted newborn pigs. Glucose utilization was linearly related to blood glucose concentration; regression analysis indicated a $y$-intercept of $7 \cdot 2 \mu \mathrm{mol} / \mathrm{kg}$ per min.

5. As tested by arterio-portal differences the gut was not releasing glucose or galactose in 5 h-post-absorptive sucking newborn pigs. Thus, the higher rates of glucose turnover in post-absorptive newborn pigs compared with fasting ones suggest that hepatic glucose production is enhanced in post-absorptive sucking piglets.

6. The mean (with SE) rates of glucose recycling were four times higher in post-absorptive piglets than in fastıng ones, i.e. $14.4(1.6)$ and $3.7(0.5) \%$ of $\left[6{ }^{3} \mathrm{H}\right]$ glucose turnover respectively. As liver glycogen was exhausted in 48-h-old sucking piglets, this suggests that hepatic glucose production results from gluconeogenesis.

Immediately after birth, the pig is fed on a high-fat, high-protein, low-carbohydrate diet (Salmon-Legagneur, 1965). Nevertheless, blood glucose concentration is maintained at normal values throughout the sucking period (Bengtsson et al. 1969), although the daily glucose intake of sucking piglets was found to be only $35-50 \%$ of the daily whole-body glucose needs (Pégorier et al. 1981).

In contrast, several studies have shown that newborn pigs develop a profound hypoglycaemia during a fast of $48 \mathrm{~h}$ beginning at birth (Swiatek et al. 1968; Gentz et al. 1970; Pégorier et al. 1981). Starvation is particularly drastic for newborn pigs, especially for cerebral metabolism, since in this species the brain does not possess the enzymes for ketone body utilization (Tildon \& Sevdalian, 1972), thus implying total dependence of the brain on glucose supply (Flecknell et al. 1982, 1983).

As liver glycogen is rapidly mobilized after birth, both in sucking and fasting newborn pigs (Swiatek et al. 1970; Pégorier et al. 1981), hepatic gluconeogenesis seems crucial for the regulation of glucose homeostasis.

Studies in vitro with isolated hepatocytes have indicated that the rates of gluconeogenesis in 48-h-old sucking pigs are two- to three-fold higher than in fasting ones (Pégorier et al. 1982), but similar to those found in 72-h-starved adult pigs (Clark et al. 1974). However, the extent to which this occurs in vivo is uncertain; both in fasting and in post-absorptive sucking newborn pigs. In previous studies performed in newborn pigs (Bayley et al. 1979; Flecknell et al. 1980, 1981a) the precise time of delivery, the onset of sucking and the glucose steady-state conditions were not clearly indicated. Moreover, the rate of glucose turnover in fasting newborn pigs is unknown. The purpose of the present work was to 
compare, under carefully controlled conditions (time of delivery, onset of sucking, environmental temperature, glucose steady-state), the rates of glucose turnover and recycling in 48-h-old fasting and post-absorptive sucking piglets using a primed continuous infusion technique. In order to compare the results with those of Flecknell et al. $(1980,1981 a)$, a single-injection method was also used.

\section{MATERIALS AND METHODS}

\section{Animals}

Pigs from the Large White strain, farrowed in the Institut National de la Recherche Agronomique (Jouy-en-Josas), were used. Pregnant sows were given $2.5 \mathrm{~kg}$ of a cereal-soya bean-meal diet daily. The lactating sows were given the same diet ad lib. In this strain, delivery normally occurs during the night of days 114-115 of pregnancy. As precise timing of birth was desired, parturition was induced by injecting pregnant sows on day 113 of gestation with a prostaglandin analogue $(10 \mu \mathrm{g}$ cloprostenol/ $\mathrm{kg}$ body-weight; Bellon, Neuilly). With this technique, piglets were delivered on the morning of day 114, i.e. 12-24 h before the normal time of delivery. Starved newborn pigs were separated from the mother immediately after birth and maintained at $34^{\circ}$ for $48 \mathrm{~h}$. Sucking newborn pigs were left with the mother under a heating lamp which maintained a local temperature of $32-33^{\circ}$ and were allowed to suck at will for $48 \mathrm{~h}$.

\section{Experimental procedures}

At $24 \mathrm{~h}$ after birth, polyethylene catheters (inner diameter $0.86 \mathrm{~mm}$; outer diameter $1.27 \mathrm{~mm}$; Lab. Bristol, Paris) were inserted under halothane anaesthesia into the external jugular vein and carotid artery in both fasting and sucking newborn pigs. The catheters were kept clear by flushing with a heparin solution $(500 \mathrm{units} / \mathrm{ml}$ saline $(9 \mathrm{~g}$ sodium chloride/1); Lab. Roche, Neuilly) and carefully capped. After surgery the newborn pigs were either immediately returned to the mother or starved and kept at $32^{\circ}$. At $1-2 \mathrm{~h}$ after surgery, the sucking newborn pigs had returned to normal sucking, suggesting that the interruption of milk intake did not exceed 3-4 h. The determination of glucose turnover, recycling and body mass were performed $24 \mathrm{~h}$ after surgery, i.e. $48 \mathrm{~h}$ after birth. In order to avoid release of glucose from the gut, sucking newborn pigs were studied 1-2 h after the last milk intake (post-absorptive piglets). During the infusion and sampling procedures the arterial and venous catheters were connected to longer ones, thus allowing the piglets to remain unrestrained during the whole time of the experiment.

\section{Mode of tracer administration}

In each experiment the $\left[6-{ }^{3} \mathrm{H}\right]$ glucose (New England Nuclear, Dreiech, W. Germany) and $\left[\mathrm{U}-{ }^{14} \mathrm{C}\right]$ glucose (Amersham International, Amersham, Bucks) were dissolved in a saline solution and administered into the external jugular vein of the fasting or post-absorptive newborn pigs.

Two modes of tracer administration were used on each newborn piglet. First, in order to determine glucose pool size and glucose distribution space, the $\left[6-{ }^{3} \mathrm{H}\right]-$ and $\left[\mathrm{U}_{-}-1{ }^{14} \mathrm{C}\right] \mathrm{glucose}$ were administered as a single injection $(4 \mu \mathrm{Ci})$ over $1 \mathrm{~min}$ at a flow-rate of $1 \mathrm{ml} / \mathrm{min}$. Blood samples were collected from the carotid artery every $3 \mathrm{~min}$ over the first $30 \mathrm{~min}$ and then every 10 min until $90 \mathrm{~min}$ after the injection of tracers (Fig. 1). At this time, the glucose specific activities were less than $0 \cdot 1$ of the initial specific activities (Fig. 1). Then, the $\left[6-{ }^{3} \mathrm{H}\right]-$ and $\left[\mathrm{U}-{ }^{14} \mathrm{C}\right] \mathrm{glucose}$ were administered by continuous infusion with a priming dose. The ratio, priming dose:infusion was 40 , i.e. a bolus of $4 \mu \mathrm{Ci}$ administered over $1 \mathrm{~min}$ and 

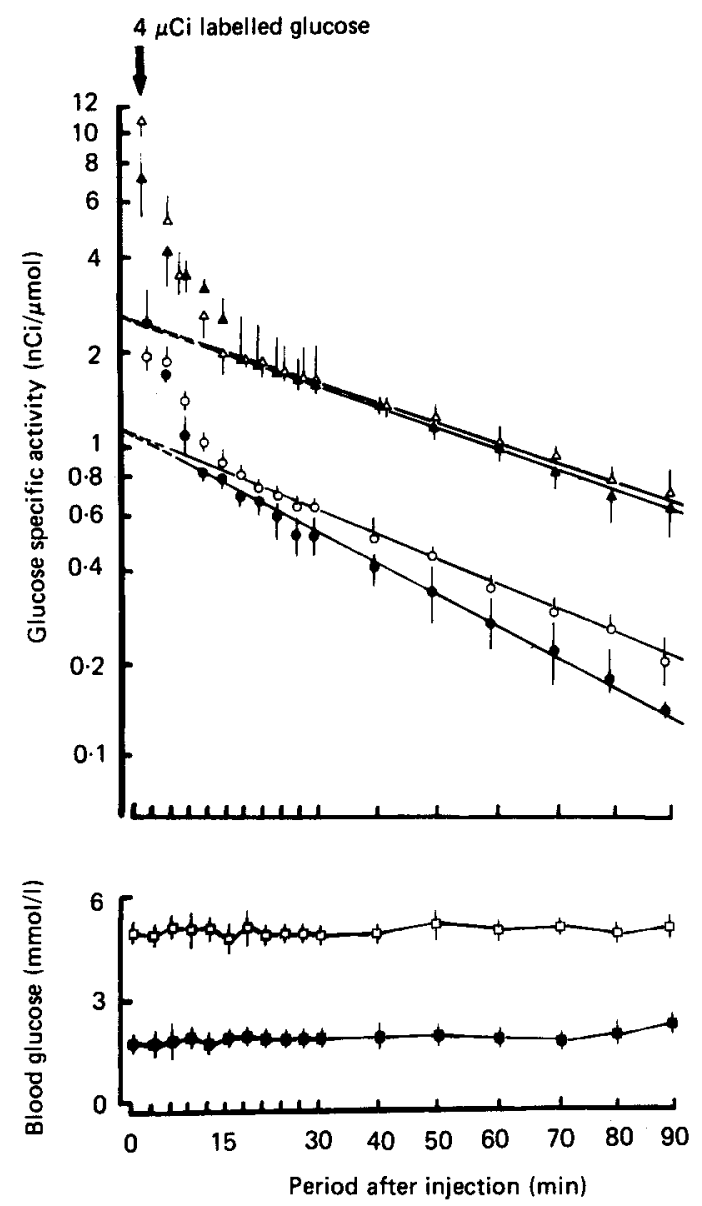

Fig. 1. Glucose specific activity $(\mathrm{nCi} / \mu \mathrm{mol})$ and blood glucose concentration $(\mathrm{mmol} / \mathrm{l})$ in 48 -h-old fasting or sucking piglets. The decreases in $\left[\mathrm{U}-{ }^{14} \mathrm{C}\right]-(\triangle)$ and $\left[6-{ }^{3} \mathrm{H}\right]$ glucose $(\Delta)$ specific activities in fasting newborn pigs and the decreases in $\left[\mathrm{U}-{ }^{14} \mathrm{C}\right]-(\mathrm{O})$ and $\left[6-{ }^{3} \mathrm{H}\right] \mathrm{glucose}(O)$ specific activities in post-absorptive newborn pigs after a single injection of the tracers into the external jugular vein. The dose injected has been normalized to $4 \mu \mathrm{Ci} / \mathrm{kg}$ per min. Blood glucose concentrations of fasting ( $\boldsymbol{\square}$ ) and post-absorptive $(\square)$ newborn pigs. Results are mean values, with their standard errors represented by vertical bars, for five to seven animals.

an infusion rate of $25 \mu \mathrm{l} / \mathrm{min}(100 \mathrm{nCi} / \mathrm{min})$. Blood samples were obtained from the carotid artery every $15 \mathrm{~min}$ during the first hour and then each $30 \mathrm{~min}$ until $3 \mathrm{~h}$ after the beginning of the experiment (Fig. 2).

\section{Chemical methods}

The arterial blood samples (100 $\mu$ l each) were deproteinized according to Somogyi (1945). After centrifugation a portion was used for glucose determination. Glucose was assayed by the glucose oxidase (EC 1.1 .3 .4$)$ method (Werner et al. 1970). The [U-14C]glucose was separated from other charged compounds using ion-exchange resin columns as described previously (Ferré et al. 1978 ). When $\left[6-{ }^{3} \mathrm{H}\right]$ glucose was used, tritiated water in the eluate 

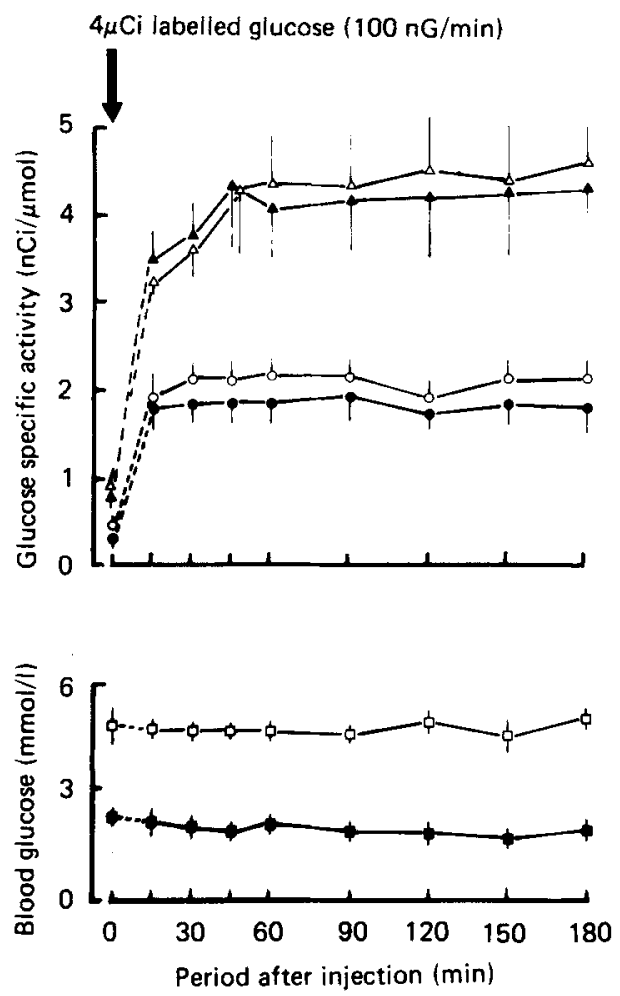

Fig. 2. Glucose specific activity and blood glucose concentration during primed continuous infusion. The $\left[\mathrm{U}-{ }^{14} \mathrm{C}\right]-(\triangle)$ and $\left[6{ }^{3} \mathrm{H}\right] \mathrm{glucose}(\Delta)$ specific activities in fasting newborn pigs and the $\left[\mathrm{U}-{ }^{14} \mathrm{C}\right]-(\mathrm{O})$ and $\left[6-{ }^{3} \mathrm{H}\right] \mathrm{glucose}(\circlearrowleft)$ specific activities in post-absorptive newborn pigs. The glucose specific activities have been standardized to a single injection of $4 \mu \mathrm{Ci} / \mathrm{kg}$ over $1 \mathrm{~min}$ and to an infusion rate of $100 \mathrm{nCi} / \mathrm{kg}$ per min. Blood glucose concentrations of fasting ( $\square$ ) and post-absorptive ( $\square$ ) newborn pigs. Concentrations and specific activities of blood glucose at zero time represent the values found $90 \mathrm{~min}$ after the start of the single injection experiments shown in Fig. 1. Results are mean values, with their standard errors represented by vertical bars, for seven to eight animals.

from resin columns was removed by evaporation. Labelled glucose was then dissolved in $500 \mu \mathrm{l}$ twice-distilled water before being counted. Under our experimental conditions the amount of label found in the resin-column eluate after evaporation corresponded to 96 (SE 3)\% of the glucose as tested by a technique previously described (Ferré et al. 1978). Labelled materials were counted in a liquid-scintillation spectrometer (Packard A 300C; United Technologies, Illinois). Corrections were made for ${ }^{14} \mathrm{C}$ spillover in the ${ }^{3} \mathrm{H}$-channel and for sample quenching.

At the end of the experiments, i.e. 5-6 h after the last milk intake, post-absorptive newborn pigs were anesthetized (15 mg sodium thiopental $/ \mathrm{kg}$ body-weight; Specia, Paris) and blood samples were collected from the portal vein and from the abdominal aorta. The blood was immediately deproteinized in ice-cold perchloric acid $(60 \mathrm{~g} / \mathrm{l})$. Glucose and galactose were determined in the neutralized perchloric filtrate by the glucose oxidase and by the galactose dehydrogenase (EC 1.1.1 .48) methods as described by Bergmeyer (1974). 


\section{Calculations}

With the single-injection technique, the rates of glucose turnover, the glucose pool size and the glucose distribution space, were calculated from the linear portion of a semilogarithmic plot describing the changes in glucose specific activity with time, as shown in Fig. 1. The semilogarithmic plot of glucose specific activity was calculated by linear regression analysis.

Glucose pool size $(M)$ was calculated as:

$$
M=D / A S_{0},
$$

where $D$ is the dose injected and $A S_{0}$ is the glucose specific activity at zero-time intercept.

Glucose distribution space $(V)$ was calculated as:

$$
V=M / G_{0},
$$

where $G_{0}$ is the blood glucose concentration at zero time.

Glucose turnover rate $(R)$ was calculated as:

$$
R=k . M,
$$

where $k$ is the slope of the semilogarithmic plot describing the changes in glucose specific activity with time.

In steady-state conditions and with the primed continuous-infusion method, the turnover rate $(\mu \mathrm{mol} / \mathrm{min})$ was calculated from the ratio, tracer infusion $(\mathrm{nCi} / \mathrm{min})$ : specific activity of glucose ( $\mathrm{nCi} / \mu \mathrm{mol})$ in the blood at equilibrium (Heath \& Barton, 1973). Whatever the techniques used (injection or primed continuous infusion), $\left[6-{ }^{3} \mathrm{H}\right]$ glucose gives the true rate of glucose turnover while the use of $\left[\mathrm{U}^{14} \mathrm{C}\right] \mathrm{glucose}$ gives the apparent rate of glucose turnover, thus allowing the determination of glucose recycling, namely the rate of glucose resynthesis from its own atoms of C (Dunn et al. 1976).

\section{Statistical methods}

Results are expressed as means with their standard errors. Statistical significance was determined by using the Wilcoxon rank test (unpaired test) and the Wilcoxon signed rank test (paired test) (Wilcoxon, 1947). Significant correlation between two indices was estimated by linear regression analysis. The sample standard deviation of the $y$-intercept and its statistical significance has been calculated according to Snedecor \& Cochran (1957).

\section{RESULTS}

The mean body-weights of the 48-h-old fasting ( 790 (SE 80) g) and of the post-absorptive (1070 (SE 90) g) newborn pigs were similar to those reported previously for newborn piglets which had had no operation (Pégorier et al. 1981).

\section{Single-injected experiments}

As shown in Fig. 1, the blood glucose concentrations remained constant during the $90 \mathrm{~min}$ of the experiment and in both groups of piglets were similar to the values found previously (Pégorier et al. 1981). Glucose specific activities have been standardized to a single injection of $4 \mu \mathrm{Ci} / \mathrm{kg}$ body-weight per min. The results obtained with this technique are summarized in Table 1. The rates of true and apparent glucose turnover were two-fold higher in post-absorptive newborn pigs than in fasting ones. With this experimental design, the glucose recycling was three-fold higher in post-absorptive piglets than in fasting ones. The glucose pool size and glucose distribution space were similar when calculated from $\left[6{ }^{3} \mathrm{H}\right]$ or $\left[\mathrm{U}-{ }^{14} \mathrm{C}\right]$ glucose values. The glucose pool size of post-absorptive newborn pigs is similar 
Table 1. Glucose turnover, recycling, pool size and distribution space in 48-h-old fasting and post-absorptive piglets, estimated with the single-injection method $\ddagger$

(Mean values with their standard errors; no. of animals in parentheses)

\begin{tabular}{|c|c|c|c|c|}
\hline & \multicolumn{4}{|c|}{ Nutritional state } \\
\hline & \multicolumn{2}{|c|}{ Post-absorptive (5) } & \multicolumn{2}{|c|}{ Fasted (7) } \\
\hline & Mean & $\mathrm{SE}$ & Mean & SE \\
\hline \multicolumn{5}{|l|}{$\begin{array}{l}\text { Turnover rate } \\
(\mu \mathrm{mol} / \mathrm{kg} \text { body-weight per } \mathrm{min}):\end{array}$} \\
\hline$\left[6^{-3} \mathrm{H}\right]$ glucose & $72 \cdot 7 * 1$ & $4 \cdot 4$ & $35 \cdot 0$ & $2 \cdot 8$ \\
\hline$\left[\mathrm{U}-{ }^{14}\right.$ Clglucose & $62 \cdot 7^{*}$ & $3 \cdot 3$ & $32 \cdot 7$ & $3 \cdot 3$ \\
\hline Rate of glucose recycling & $13 \cdot 7^{*}$ & 2.7 & $5 \cdot 1$ & 0.9 \\
\hline \multicolumn{5}{|l|}{$\begin{array}{l}\text { Glucose pool size } \\
(\mathrm{mmol} / \mathrm{kg} \text { body-weight }) \text { : }\end{array}$} \\
\hline$\left[6-{ }^{3} \mathrm{H}\right]$ glucose & $2.93^{*}$ & $0 \cdot 24$ & 1.66 & 0.03 \\
\hline [U-14C]glucose & $3 \cdot 02^{*}$ & 0.20 & 1.77 & 0.13 \\
\hline \multicolumn{5}{|l|}{$\begin{array}{l}\text { Glucose distribution space } \\
\text { (ml/kg body-weight) }\end{array}$} \\
\hline$\left[6-{ }^{3} \mathrm{H}\right]$ glucose & 594 & 72 & 591 & 86 \\
\hline [U-14C]glucose & 611 & 67 & 626 & 84 \\
\hline
\end{tabular}

* Mean value significantly different from fasting value $(P<0.01$; Wilcoxon unpaired test).

$\dagger$ Mean value significantly different from $\left[U-{ }^{14} \mathrm{C}\right]$ glucose value $(P<0.01$; Wilcoxon paired test $)$.

$\ddagger$ For details of procedures, see p. 278.

to that reported by Flecknell et al. (1980). In 48-h-old post-absorptive or fasting newborn pigs the glucose distribution space is similar to that reported in newborn rats (Vernon \& Walker, 1972; Ferré et al. 1978) or newborn primates (Robinson et al. 1980) but two- to three-fold higher than in older pigs (Riis \& Grummer, 1969; Trayhurn et al. 1981; Cote et al. 1982; Müller et al. 1983), as has been shown in other mammalian species.

\section{Primed infusion experiments}

A constant blood glucose concentration was maintained during the infusion (Fig. 2). Glucose specific activities have been standardized to a priming dose of $4 \mu \mathrm{Ci} / \mathrm{kg}$ body-weight per min and to an infusion rate of $100 \mathrm{nCi} / \mathrm{kg}$ body-weight per min. As $\left[6{ }^{3} \mathrm{H}\right]$ - and $\left[\mathrm{U}-{ }^{14} \mathrm{C}\right]$ glucose specific activities reached constant values $15 \mathrm{~min}$ after the beginning of the continuous infusion, the rates of glucose turnover of post-absorptive newborn pigs were calculated from all the values between 15 and $180 \mathrm{~min}$ after the priming dose (Fig. 2). For fasting newborn pigs, the $\left[6-{ }^{3} \mathrm{H}\right]$ - and $\left[\mathrm{U}-{ }^{14} \mathrm{C}\right]$ glucose specific activities reached a steady-state only after $45 \mathrm{~min}$ (Fig. 2) and consequently the rates of glucose turnover were calculated from all the values between 45 and $180 \mathrm{~min}$. For both groups, the results are summarized in Table 2. As found previously using the single injection method, the rates of $\left[6-{ }^{3} \mathrm{H}\right]-$ and $\left[\mathrm{U}-{ }^{14} \mathrm{C}\right]$ glucose turnover were two-fold higher in post-absorptive than in fasting newborn pigs. The rate of glucose recycling, calculated for each animal as the difference between [6- $\left.{ }^{3} \mathrm{H}\right]-$ and $\left[\mathrm{U}-{ }^{14} \mathrm{C}\right]$ glucose turnover rates, was five-fold higher in post-absorptive newborn pigs than in fasting ones (Table 2). 
Table 2. Glucose turnover and recycling in 48-h-old fasting and post-absorptive piglets using the primed continuous infusion method $\$$

(Mean values with their standard errors; no. of animals in parentheses)

\begin{tabular}{|c|c|c|c|c|}
\hline & \multicolumn{4}{|c|}{ Nutritional state } \\
\hline & \multicolumn{2}{|c|}{ Post-absorptive (7) } & \multicolumn{2}{|c|}{ Fasted (8) } \\
\hline & Mean & $\mathbf{S E}$ & Mean & $\mathrm{SE}$ \\
\hline \multicolumn{5}{|l|}{$\begin{array}{l}\text { Turnover rate } \\
(\mu \mathrm{mol} / \mathrm{kg} \text { body-weight per } \mathrm{min})\end{array}$} \\
\hline$\left[6-{ }^{3} \mathrm{H}\right]$ glucose & $65 \cdot 0^{*+}+$ & $2 \cdot 8$ & $29 \cdot 4$ & $3 \cdot 3$ \\
\hline [U-14C]glucose & $53 \cdot 8^{*}$ & $3 \cdot 3$ & $28 \cdot 3$ & $2 \cdot 2$ \\
\hline $\begin{array}{l}\text { Rate of glucose recycling } \\
\left(\% \text { of }\left[6^{-}{ }^{-} \mathrm{H}\right] \text { glucose turnover }\right)\end{array}$ & $14.9^{*}$ & $2 \cdot 0$ & $3 \cdot 1$ & 0.8 \\
\hline
\end{tabular}

* Mean value significantly different from fasted value $(P<0.01$; Wilcoxon unpaired test).

$\dagger$ Mean value significantly different from $\left[\mathrm{U}-{ }^{14} \mathrm{C}\right]$ glucose value $(P<0.01$; Wilcoxon paired test).

$\ddagger$ For details of procedures, see p. 278.

\section{Relationship between blood glucose concentration and glucose turnover rate}

If the individual true glucose turnover rates of post-absorptive and fasting newborn pigs are plotted against their respective blood glucose concentrations, there is a linear relationship between them $(r 0.877, P<0.01, n 27$; Fig. 3).

\section{Glucose and galactose arterio-portal differences in post-absorptive newborn pigs}

In order to test whether glucose and galactose were produced by the gut from lactose previously ingested by post-absorptive sucking newborn pigs, glucose and galactose concentrations were determined in the portal vein and in the abdominal aorta. At the end of the glucose turnover experiments, i.e. 5-6 h after the last milk intake, the mean blood glucose concentrations $(\mathrm{mmol} / \mathrm{l})$ in the portal vein and in the abdominal aorta were respectively $4 \cdot 17$ (SE $0.83, n 6$ ) and $4 \cdot 61$ (SE $0 \cdot 72, n 6$ ). The mean blood galactose concentrations $(\mu \mathrm{mol} / \mathrm{l})$ were 2.4 (SE $1 \cdot 3, n 6)$ in the portal vein and 5.0 (SE 3.6, $n$ 6) in the abdominal aorta. Thus at the end of the experiments the gut was not releasing glucose or galactose from previously ingested lactose. Preliminary experiments performed with another series of post-absorptive newborn piglets showed that, $2 \mathrm{~h}$ after the last milk intake, the gut was not releasing glucose or galactose from previously ingested lactose. This suggests that no glucose was released from the gut from the beginning of the tracer injection onwards.

\section{DISCUSSION}

Since the rates of glucose turnover in 48-h-old fasting or post-absorptive piglets were not statistically different when measured using the single-injection technique or the primed infusion method, they have been pooled. Mean rates of glucose turnover were 65.8 (SE 2.5$) \mu \mathrm{mol} / \mathrm{kg}$ body-weight per $\min (n 12)$ for $\left[6-{ }^{3} \mathrm{H}\right]$ glucose in post-absorptive newborn pigs and 31.1 (SE 1.9) $\mu \mathrm{mol} / \mathrm{kg}$ body-weight per min $(n 15)$ in fasting piglets. The glucose turnover rate of post-absorptive newborn pigs in the present study was $30 \%$ higher than that found by Flecknell et al. $(1980,1981 a)$. Although these authors used $\left[2-{ }^{3} \mathrm{H}\right] \mathrm{glucose}$, 


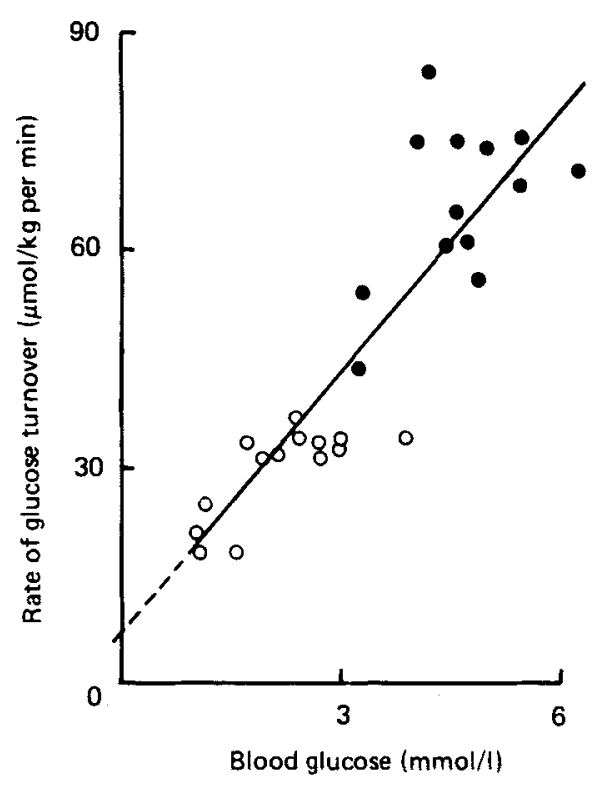

Fig. 3. Blood glucose concentration and $\left[6-{ }^{3} \mathrm{H}\right]$ glucose turnover rate. The relation between blood glucose concentration and true glucose turnover rate in 48-h-old fasting $(O)$ or post-absorptive $(O)$ piglets.

$$
y=11.66 x+7 \cdot 2, \quad r 0.877, P<0.01
$$

this cannot be the only explanation since it has been shown that use of $\left[2-{ }^{3} \mathrm{H}\right]$ glucose leads to an overestimation of glucose turnover rate due to the loss of tritium in the isomerization of glucose-6-phosphate to fructose-6-phosphate (Dunn et al. 1976). It seems also unlikely that the higher rate of glucose turnover found in the present study resulted from a release of glucose from the gut. A possible difference between the work of Flecknell et al. $(1980,1981 a)$ and ourselves arises from the nutritional conditions. In their experiments (Flecknell et al. 1981 a) 48-h-old post-absorptive pigs were fasted for $16 \mathrm{~h}$ before tracer administration and thus had a lower blood glucose concentration $(3.77 \mathrm{mmol} / \mathrm{l})$ than in the present study $(4.89 \mathrm{mmol} / \mathrm{l})$. At the blood glucose concentration observed in the studies of Flecknell et al. (1981a) it can be calculated from the results shown in Fig. 3 that the expected rate of glucose turnover would be $50 \mu \mathrm{mol} / \mathrm{kg}$ per min, a value within the range found by these authors ( 40 (SE 10) $\mu \mathrm{mol} / \mathrm{kg}$ per min).

In contrast with the work of Flecknell et al. $(1981 \mathrm{~b})$ the present study showed that the rate of glucose turnover is related to blood glucose concentration (Fig. 3). Similar results have been reported in newborn rats (Ferré et al. 1980), newborn dogs (Kliegman et al. 1980) and newborn primates (Robinson et al. 1980). As these experiments were conducted in steady-state conditions the rate of glucose production equals the rate of glucose utilization. These two aspects will be discussed separately.

\section{Glucose utilization}

The higher rates of glucose utilization in post-absorptive newborn pigs compared with fasting ones are associated with increased concentrations of blood glucose and insulin (Pégorier et al. 1981). Among the various tissues responsible for the utilization of the additional glucose, the skeletal muscles and the intestinal wall (as suggested by arterio-portal 
differences) could represent the major sites responsible for increased glucose utilization. Although glucose utilization is linearly related to blood glucose concentration, regression analysis indicated a $y$-intercept of 7.2 (SE 1.6) $\mu \mathrm{mol} / \mathrm{kg}$ per min (Fig. 3). This positive intercept indicates that at blood glucose concentrations between 0 and $1.5 \mathrm{mmol} / \mathrm{l}$, glucose utilization increases more rapidly as a function of blood glucose concentration than it does at higher blood glucose concentrations, thus suggesting that some tissues do not increase their glucose utilization in proportion to an increase in blood glucose concentration. This is true for non-insulin-dependent tissues, such as the brain, which possess a high affinity for glucose but a rapidly saturated capacity for glucose utilization (Growdon et al. 1971). Indeed, the value of the $y$-intercept found in the present study $(7.2 \mu \mathrm{mol} / \mathrm{kg}$ per $\mathrm{min})$ is closely related to the rate of glucose utilization by the brain of newborn piglets $(8 \mu \mathrm{mol} / \mathrm{kg}$ per min; Flecknell et al. 1982, 1983). Similar conclusions were drawn for adult humans (Best et al. 1981; Verdonk et al. 1981) and adult dogs (Cherrington et al. 1978).

The glucose turnover rates found in 48-h-old post-absorptive piglets, when expressed per $\mathrm{kg}$ body-weight, were two- to three-fold higher than in post-weaning piglets. In piglets of $20 \mathrm{~kg}$ body-weight, glucose utilization was $15-25 \mu \mathrm{mol} / \mathrm{kg}$ per min (Riis \& Grummer, 1969; Freeman et al. 1970; Trayhurn et al. 1981; Cote et al. 1982). A more accurate comparison between newborn and growing animals may be made on the basis of the metabolic body size which is related to the basal metabolic rate (Ballard et al. 1969). From this, glucose turnover rate is calculated to be $67 \mu \mathrm{mol} / \mathrm{kg}$ body-weight ${ }^{0 \cdot 75}$ per min for sucking newborn pigs, a value 1.5 -fold higher than in post-weaning pigs $\left(43 \mu \mathrm{mol} / \mathrm{kg}\right.$ body-weight ${ }^{0.75}$ per $\mathrm{min})$. The reasons for this enhanced glucose utilization in sucking newborn pigs are not known, but it seems unlikely that it could be due to a greater muscle mass since muscle forms a similar proportion of body-weight in newborn pigs $(33 \%$ body-weight; $P$. H. Duée and C. Kohl, unpublished results) as in older animals (30\% body-weight; Davies, 1974). Part of the difference could result from the proportionately larger brain in newborn piglets $(30 \mathrm{~g} / \mathrm{kg}$ in the newborn $v .2 \mathrm{~g} / \mathrm{kg}$ in older piglets; Flecknell et al. 1980). In keeping with this it has been shown in piglets (Flecknell et al. 1980) and in humans (Bier et al. 1977) that there is a remarkable correlation between glucose turnover and estimated brain weight during development. Moreover, human neonates with reduced cephalic mass have a glucose turnover rate similar to that in adults (Schwartz \& Kahlan, 1975).

\section{Glucose production}

The higher rate of glucose production in post-absorptive newborn pigs compared with fasting ones suggests that sucking newborn piglets subjected to a relatively short period of starvation are able to maintain a normal blood glucose concentration through an increase in glucose production rather than a decrease in glucose utilization. As liver glycogen stores are totally exhausted $24 \mathrm{~h}$ after birth in sucking newborn pigs (Swiatek et al. 1970; Pégorier et al. 1981), this suggests that glucose production, at least in post-absorptive newborn pigs, is supported by hepatic gluconeogenesis. Moreover, the existence of a four-fold higher rate of glucose recycling in post-absorptive newborn pigs compared with fasting ones suggests that hepatic gluconeogenesis is more active in the post-absorptive state than during a prolonged fast beginning at birth. Similar results have been reported in isolated hepatocytes from fasting and sucking newborn pigs (Pégorier et al. 1982) and could explain why sucking piglets remain normoglycaemic despite a high-fat, low-carbohydrate diet whereas fasting newborn pigs rapidly develop hypoglycaemia. Taking into account the rate of glucose recycling (10 (SE 1) $\mu \mathrm{mol} / \mathrm{kg}$ body-weight per min, i.e. 14.4 (SE 1.6$) \%$ of $\left[6-{ }^{3} \mathrm{H}\right]$ glucose turnover, Tables 1 and 2) the net glucose needs of sucking newborn pigs can be estimated to be 57.7 (SE $2 \cdot 2$ ) $\mu \mathrm{mol} / \mathrm{kg}$ body-weight per min, i.e. approximately $80 \mathrm{mmol}$ glucose $/ \mathrm{kg}$ body-weight per $\mathrm{d}$. Knowing the daily colostrum intake $(200-300 \mathrm{ml})$ and its 
composition ( $\mathrm{g} / \mathrm{kg}$; $60 \mathrm{fat}, 100$ protein, 40 lactose) (Salmon-Legagneur, 1965), one can assume that $25 \mathrm{mmol}$ glucose $/ \mathrm{kg}$ can be supplied by lactose from the colostrum to the sucking piglets. Thus, hepatic gluconeogenesis must provide $55 \mathrm{mmol}$ glucose $/ \mathrm{kg}$ per $\mathrm{d}$, i. e. $60 \%$ of the glucose turnover rate. A similar gluconeogenic activity during the neonatal period has been reported in human neonates (Bier et al. 1977), newborn lambs (Cowett et al. 1978) and newborn rats (Ferré et al. 1980). Active gluconeogenesis in post-absorptive newborn piglets is probably sustained by the supply of potential gluconeogenic precursors (galactose, glycerol, amino acids) from the milk constituents. Calculation shows that galactose and glycerol from the milk provide at most $25 \mathrm{mmol}$ glucose $/ \mathrm{kg}$ per $\mathrm{d}$ and $8 \mathrm{mmol}$ glucose $/ \mathrm{kg}$ per $\mathrm{d}$ respectively (assuming that $8 \%$ of milk fat is glycerol). This theoretical calculation shows that if glycerol were exclusively used to satisfy active gluconeogenesis this would represent only $10 \%$ of the rate of glucose turnover. As glucose turnover rate is $80 \mathrm{mmol} / \mathrm{kg}$ per $\mathrm{d}$, this implies that amino acids from protein must supply $20 \mathrm{mmol}$ of glucose, which represents only $25 \%$ of protein intake, a value which is in agreement with the high nitrogen accretion during the neonatal period (Aumaître \& Duée, 1974).

The authors are indebted to Dr P. Ferré for helpful advice and discussion, C. Kohl and M. Bonneau for their expert technical assistance. They thank S. Seige and S. Finel for their careful preparation of the manuscript. This work was supported in part by the Institut National de la Santé et de la Recherche Médicale (RCP 50-85-38).

\section{REFERENCES}

Aumaître, A. \& Duée, P. H. (1974). Annales de Zootechnie 23, 231-236.

Ballard, F. J., Hanson, R. W. \& Kronfeld, D. S. (1969). Federation Proceedings 28, $218-231$.

Bayley, H. S., Crozier, G. L. \& Atkinson, J. L. (1979). In Energy Metabolism, pp. $439-443$ [L. E. Mount, editor]. London: Butterworths.

Bengtsson, G., Gentz, J., Hakkarainen, J., Hellstrom, R. \& Person, B. (1969). Journal of Nutrition 97, $311-315$. Bergmeyer, H. U. (1974). Methods of Enzymatic Analysis, pp. 1279-1281. New York: Academic Press.

Best, J. D., Taborsky, G. J., Halter, J. B. \& Porte, D. Jr (1981). Diabetes 30, 847-850.

Bier, D. M., Leake, R. D., Haymond, M. W., Arnold, K. J., Gruenke, L. D., Sperling, M. A. \& Kipnis, D. M. (1977). Diabetes 26, 1016-1023.

Cherrington, A. D., Williams, P. E. \& Harris, M. S. (1978). Metabolism 27, 787-791.

Clark, M. G., Bloxham, D. P., Holland, P. C. \& Lardy, H. A. (1974). Journal of Biological Chemistry 249, $279-290$.

Cote, P. J., Wangsness, P. J., Varela-Alvarez, H., Griel, L. C. Jr \& Kavanaugh, J. F. (1982). Journal of Animal Science 54, 89-94.

Cowett, R. M., Susa, J. B., Oh, W. \& Schwartz, R. (1978). Pediatric Research 12, 853-857.

Davies, A. S. (1974). Animal Production 19, 367-376.

Dunn, A., Katz, J., Golden, S. \& Chenoweth, M. (1976). American Journal of Physiology 230, $1159-1162$.

Ferré, P., Pégorier, J. P., Marliss, E. B. \& Girard, J. R. (1978). American Journal of Physiology 234, E129-E136.

Ferré, P.,Turlan, P. \& Girard, J. R. (1980). Journal of Developmental Physiology 2, 373-387.

Flecknell, P. A., Wootton, R. \& John, M. (1980). British Journal of Nutrition 44, 193-203.

Flecknell, P. A., Wootton, R. \& John, M. (1981a). Clinical Science 60, 335-338.

Flecknell, P. A., Wootton, R. \& John, M. (1982). Biology of the Neonate 41, 221-226.

Flecknell, P. A., Wootton, R. \& John, M. (1983). Clinical Science 64, 161-165.

Flecknell, P. A., Wootton, R., John, M. \& Royston, J. P. (1981 b). Canadian Journal of Physiology and Pharmacology 59, 1069-1072.

Freeman, C. P., Noakes, D. E. \& Annisson, E. F. (1970). British Journal of Nutrition 24, 705-716.

Gentz, J., Bengtsson, J. K., Hakkarainen, J., Hellstrom, R. \& Persson, B. (1970). American Journal of Physiology 218, 662-668.

Growdon, W. A., Bratton, T. S., Houston, M. C., Tarplex, H. L. \& Regen, D. M. (1971). American Journal of Physiology 221, 1733-1745.

Heath, D. F. \& Barton, R. N. (1973). Biochemical Journal 136, 503-518.

Kliegman, R. M., Miettinen, E. L. \& Adam, P. A. J. (1980). American Journal of Physiology 239, E287-E293.

Müller, M. J., Paschen, U. \& Seitz, H. J. (1983). American Journal of Physiology 244, E236-E244. 
Pégorier, J. P., Duée, P. H., Assan, R., Peret, J. \& Girard, J. R. (1981). Journal of Developmental Physiology 3, 203-217.

Pégorier, J. P., Duée, P. H., Girard, J. R. \& Peret, J. (1982). Journal of Nutrition 112, 1038-1046.

Riis, P. M. \& Grummer, R. H. (1969). Acta Agriculturae Scandinavica 19, 11-17.

Robinson, B. H., Sherwood, W. G., Mayes, S., Freire, E., Oei, J. \& Dibattista, D. (1980). Biology of the Neonate 37, 60-66.

Salmon-Legagneur, E. (1965). Annales de Zootechnie 14, 1-137.

Schwartz, R. \& Kahlan, S. (1975). In Progress in Clinical and Biological Research, vol. 2. Preventability of Perinatal Injury, pp. 187-200 [K. Adamson and H. A. Fox, editors]. New York: A. R. Liss Inc.

Snedecor, G. W. \& Cochran, G. W. (1957). Statistical Methods, 6th ed. Ames, Iowa: Iowa State College Press.

Somogyi, M. (1945). Journal of Biological Chemistry 160, 69-73.

Swiatek, K. R., Chao, K. L., Chao, H. L., Cornblath, M. \& Tildon, J. T. (1970). Biochimica et Biophysica Acta 222, 145-151.

Swiatek, K. R., Kipnis, D. M., Mason, G., Chao, K. L. \& Cornblath, M. (1968). American Journal of Physiology 214, 400-405.

Tildon, J. T. \& Sevdalian, D. A. (1972). Archives of Biochemistry and Biophysics 148, 382-390.

Trayhurn, P., Dauncey, M. J. \& Ingram, D. L. (1981). Comparative Biochemistry and Physiology 69B, 69-73.

Verdonk, C. A., Rizza, R. A. \& Gerich, J. E. (1981). Diabetes 30, 535-537.

Vernon, R. G. \& Walker, D. G. (1972). Biochemical Journal 127, 521-529.

Werner, W., Rey, H. G. \& Wellinger, M. (1970). Zeitschrift für Analytisch Chemie 252, $224-228$.

Wilcoxon, F. (1947). Biometrics 3, 119-122. 